\title{
Min årstid er høsten
}

\author{
Han må ha sin daglige dose poesi for å trives, Egil W. Martinsen. Favoritten er Hans Børli, som brukte både \\ kropp og sjel i sitt arbeid.
}

Nervøsiteten forsvinner idet jeg møter ham. En høy mann med et vennlig blikk fyller døråpningen.

- Vil du ha en kopp kaffe? spør han med mild røst mens jeg setter meg til rette i en lenestol ved vinduet. Utenfor faller løvet fra trær som viser seg i vakker fargeprakt.

- Jeg hoster sånn, så jeg må ha en kopp selv også.

Egil Martinsen er psykiater og har 20 års erfaring med behandling av angstlidelser. Nå sitter han som professor II ved Universitetet i Oslo og er leder for forsknings- og utviklingsavdelingen ved Klinikk for psykisk helse og avhengighet ved Oslo universitetssykehus. Jeg ser meg omkring på kontoret mens han henter kaffen. Over skrivebordet henger et bilde i blå toner av dikteren Hans Børli. På bordet står en byste av Sokrates. En plakat fra en westernfilm henger ved siden av bokhyllen, som er fylt med diktsamlinger og skjønnlitteratur, i tillegg til alle fagbøkene. På døren henger et bilde av løpere i ferd med å krysse målstreken.

- Det er ikke meg, det er drømmen om meg, ler Martinsen og lukker døren bak seg. - John Walker heter han som vant. Det er finalen på 1500 meter i olympiaden i 1976.

Som guttunge ville legen bli langrennsløper og tømmerhogger.

- Jeg endte opp med å lese Børli og hogge ved på hytta, sier han humrende.

Hans Børli var tømmerhogger og er den norske dikteren Egil Martinsen setter høyest.

- Han gledet seg til å bli pensjonist, for da skulle han få mer tid til å skrive. Så fikk han hjerteinfarkt. Han ble uførepensjonert og fikk all verdens tid til å dikte. Men da kom ikke diktene til ham som før. Det var den fysiske anstrengelsen, kroppsarbeidet i skogen, som forløste skaperkraften i ham.

\section{Kropp og sinn henger sammen}

At fysisk aktivitet er viktig for sjelslivet, har Egil Martinsen vitenskapelige bevis for. Da han som ung lege begynte på Modum Bad, ble han bekymret over hvor stillesittende livet var for pasientene på avdelingen. - Jeg bestemte meg for å lage et treningsopplegg.

Snart var han i gang med det som skulle bli hans doktorgradsprosjekt.

- Tre arbeidsterapitimer ble erstattet med trening, resten av terapien fortsatte som før.

Etter tre måneder var pasientene som hadde trent, signifikant bedre av sin depresjon enn de som ikke hadde trent.

- Faget psykiatri begrenses ofte til samtaler og medisiner, og det er lett å glemme kroppen. Men psykiske lidelser påvirker hele mennesket, også kroppen.

I 2004 ga Martinsen ut en bok om temaet: Kropp og sinn. Fysisk aktivitet og psykisk helse.

- Jeg er veldig glad for at myndighetene etter hvert har tatt dette på alvor.

Da Dagfinn Høybråten opprettet Nasjonalt råd for fysisk aktivitet, ble Egil Martinsen bedt om å være med. Han er også en av forfatterne bak Aktivitetshåndboken, som ble utgitt av Helsedirektoratet i 2009.

- Aktivitetshåndboken beskriver hvordan fysisk aktivitet kan brukes til å forebygge og behandle både somatisk og psykisk sykdom. - Er trening like viktig i psykiatrien som ved somatiske sykdommer?

- Ja, det mener jeg bestemt. Ta for eksempel pasienter med schizofreni. De har en betydelig økt risiko for hjerte- og karsykdommer og en forventet levealder som ligger 10-15 år under gjennomsnittet $\mathrm{i}$ befolkningen, delvis på grunn livsstilsfaktorer som fysisk inaktivitet. Det er egentlig ganske dramatisk. I tillegg er fysisk aktivitet gunstig for den psykiske helsen også for denne pasientgruppen. - Det burde være enkelt å sette i gang tiltak?

- Nettopp det er problemet. Det er for enkelt. Kosthold og aktivitet er så banalt, så lite intellektuelt utfordrende. Men grunnlaget for helse er ikke å la kroppen forfalle. Da er jo aktivitet og kosthold nøkkelpunktene. Fortsatt ser vi at pasienter på psykiatriske avdelinger, hvor det ikke er et systematisk tilbud om fysisk aktivitet og et bevisst kosttilbud, går opp betydelig i vekt mens de er innlagt. Pasientene forfaller fysisk mens de får hjelp med sine psykiske helseproblemer. Jeg synes det er alvorlig, sier Martinsen.

- Mennesket er kropp, sjel og ånd. I min fortid i KFUM hadde vi et symbol med en trekant som tegn for dette. Så var det en ring rundt trekanten for å vise at dette henger sammen. Jeg synes det er et fint symbol.

\section{Moralterapi}

På asylet på Gaustad i 1850-årene fikk pasientene såkalt moralterapi.

- De hadde ikke farmaka eller psykoterapi. I stedet fikk pasientene delta $i$ arbeidet på Gaustad gård og stelle dyr og planter. På slutten av 1800-tallet begynte kritiske røster å spørre om dette var terapi eller utnytting av svake mennesker.

Dermed forsvant aktiviteten og kontakten med dyrene. Men det spørs om det ikke ble kastet ut noen barn med badevannet, sier Martinsen.

Nå er kontakt med dyr og stell av planter på vei inn igjen i psykiatrien.

- Jeg er en av veilederne for prosjekter ved Universitetet på Ås der stell av planter og dyr inngår i rehabiliteringen av mennesker med psykiske plager. Det synes jeg er veldig artig, forteller han.

På Gaustad har man en stall med hester.

- Ridning og stell av hest og stall inngår $i$ behandlingen av unge rusmisbrukere. Vi ser at kontakt med dyr kan være positivt der vanlige samtaler ikke når frem.

Gaustad sykehus har også arrangert kurs som har vært veldig populære.

- Vi kalte kursene «Psykisk helsearbeid mer enn samtale og medisiner». Én foredragsholder snakket om musikk, noen snakket om kosthold, noen om stell av planter og dyr og noen om arbeid og kunstterapialle de tingene som er viktige for psykisk helse utover den klassiske skolemedisinen. I januar gir vi ut en bok med samme tittel.

Han avbryter pluselig seg selv.

- Nå prater jeg fælt. Jeg er egentlig mest vant til å lytte.

- Er det ikke godt å få snakke litt da?

- Jo, det er fint når noen hører på, medgir Martinsen og knegger av latter.

\section{Den gode samtalen}

- «Eit ord - ein stein i ei kald elv. Ein stein til - Eg lyt ha fleire steinar skal eg koma yver.»

Psykiateren har mange dikt lagret i minnet. - Det var et vakkert bilde på samtalen.

- Ja, en metafor kan ofte være til god hjelp når man skal beskrive opplevelser og følelser. Jeg liker godt Olav H. Hauge. Han skriver kort, nesten litt haikuaktig.

Egil Martinsen tyr til poesien i terapitimer og når han underviser.

- Kognitiv terapi er et av dine hjertebarn. Hva handler det om?

- Kognitiv terapi er en form for samtaleterapi. Psykiske plager påvirker hele mennesket; kroppen, følelsene, tankene og atferden vår. Metoden sier at du ikke kan påvirke følelsene direkte. Du kan ikke si «Ikke vær lei deg!» til en deprimert, eller til 


\section{Egil Wilhelm Martinsen}

\section{Født 19. mai 1950 i Oslo}

- Cand.med. 1976

- Spesialist i psykiatri 1985

- Professor II i psykiatri, Universitetet i Oslo, 2007

- Utga boken Kropp og sinn. Fysisk aktivitet og psykisk helse i 2004

- Medredaktør av boken Psykisk helsearbeid - mer enn samtale og medisiner som utgis i januar 2011

Foto Kari Tveito en med angst «Ikke vær redd!». Men man kan påvirke følelsene ved å få tak i hvordan folk tenker, og se om det finnes andre og mer hensiktsmessige måter å tenke på. Det er den tankemessige delen av kognitiv terapi. Så finnes det en del av terapien som retter seg mot å forandre atferd. Folk som er deprimerte, har en tendens til å trekke seg tilbake og bli inaktive. Isolasjon hjelper på kort sikt, men opprettholder depresjonen på lang sikt. Ved å endre på atferden, kan du bedre depresjonen. Her kommer fysisk aktivitet inn, som en form for atferdsaktivering. Lite hensiktsmessige tankemønstre kan også være med på å forsterke somatiske symptomer, forteller Martinsen.

- Jeg veileder en lege i Molde som holder på med et veldig spennende prosjekt. Han har undersøkt pasienter som er henvist til hjertepoliklinikk på grunn av hjertebank eller brystsmerter. De aller fleste hadde ikke hjertesykdom, men $40 \%$ av pasientene som ikke fikk påvist hjertesykdom, hadde psykiatrisk sykdom. Seks måneder etter at de fikk vite at det ikke var noe galt med hjertet, ble pasientene intervjuet på nytt. Overraskende nok hadde mange av pasientene sterkere symptomer enn før, sier han.

- Prosjektet viser at folk ikke nødvendigvis blir friske bare av å få vite at de ikke har en alvorlig somatisk sykdom. Spørsmålet er hva du kan gjøre for disse pasientene. Her kommer kognitiv terapi inn i bildet. Pasientene må få hjelp til å bli klar over hvordan de fortolker sine plager, oppdage at det finnes ander måter å tenke om problemet på, og gjenoppta normal livsstil, inkludert fysisk aktivitet, på tross av plagene.

\section{Blå i bånn}

Kursene i kognitiv terapi som Egil Martinsen og medarbeiderne holder for allmennpraktikere, og siden i vår også for medisinstudenter, er populære.

- Fordelen med å bruke kognitiv terapi er at det bygger på common sense. Hvis du tror at hjertebank er et forvarsel om død, er det klart at du blir engstelig. Det er ikke smerteopplevelsen, men hva du tenker rundt det, som er problemet.

- Benytter du disse teknikkene i det daglige selv?

- Jeg er blitt mer oppmerksom på hvordan jeg tenker, og hvordan andre tenker. Men jeg tror det er lett å overvurdere psykiatere og psykologer og tro at de ser rett gjennom deg. Jeg har ikke fått det til i alle fall. Ikke har jeg så lyst til det heller. Det er ikke så farlig å være i selskap med meg, for jeg er ikke så veldig tolkende og analyserende som person. Da blir jeg jo utenfor. - Du vil heller være deltaker?

- Ja, det er mer gøy. Da må du ta folk som de er.

- Du er opptatt av å ha det morsomt?

- Jeg prøver å motvirke tungsinnet, vet du. Når man har en blå grunnstemning, får man prøve å finne lyspunktene. - Du virker ikke så veldig blå?

- Nei, men jeg er blå i bånn. Jeg vet det. Børli var også blå. De fleste diktere er blå. «Min årstid er høsten», skriver Arild Nyquist. - Hva sier du da?

- Jeg skulle til å si «det går mot kveld», men det er kanskje litt mørkt.

- Jeg får ikke dette til å rime med entusiasmen din?

- Jeg er heldigvis blitt kjent med mange ildsjeler som er opptatt av lignende ting som meg selv. Jeg blir smittet av dem.

Han er takknemlig for at han fortsatt har en slik evne til å bli ivrig. Men når man jobber med mennesker med angst og depresjon, kan det være en fordel at man kan skjønne litt av hvordan de har det, tror han.

- Hva er livets grunnbetingelser? Jo, ensomhet, fremmedgjøring og frykt for døden. Martinsen humrer igjen. - Man må finne en måte å leve med det på.

- Hva er du mest stolt over å ha fått til?

- Ved siden av at jeg har vært så heldig å ha et stabilt familieliv? Det jeg er mest fornøyd med, er kanskje at jeg sammen med gode medarbeidere fikk klinikken i Førde i gang.

I 1988 ble Egil Martinsen headhuntet til lederstillingen ved den nyopprettede psykiatriske avdelingen ved Sentralsjukehuset i Sogn og Fjordane.

- Etter 12 år reiste vi tilbake til Østlandet. Jeg var ikke vestlending nok, selv om moren min er fra Sunnfjord. Jeg ble aldri helt fortrolig med søndagsturer i regnvær i januar.

Han blir alvorlig igjen.

- Det er ikke så mange ting jeg er virkelig stolt over. Der, i det selvkritiske, ligger noe av det blå, tror jeg. For en tid tilbake ble en lege som heter Karl Otto Nakken, intervjuet i Tidsskriftet, husker du det? Han er formann i MOL: Melankolske Overlegers Landsforening. Jeg er styremedlem.

- Nå tuller du.

- Jo, jeg er styremedlem. Han fikk så mange henvendelser etter det intervjuet at han innkalte til stiftelsesmøte. De som møtte opp, ble med i styret. Leger flest kunne godt være flinkere til å søke gjensidig støtte hos hverandre, mener Martinsen.

- Det går an å kunne hjelpe andre uten å kunne hjelpe seg selv. Da vi bodde på Vestlandet, hendte det en kveld at jeg ble oppringt fra sykehuset. En kollega hadde mistet moren $\sin$. Sykehuset hadde den ordningen at de kontaktet familie eller venner til pårørende av pasienter som døde. Siden vedkommende var flyktning og ikke hadde annen familie i Norge, ringte han til meg. «Jeg må ned på sykehuset en tur, » forklarte jeg min yngste sønn, som da var ti år gammel og satt og lekte med en kamerat. «Det er en psykiater som har mistet moren sin, og jeg må snakke med ham.» «Trenger han å snakke med noen, han som som er psykiater?» spurte sønnen min. «En psykiater kan ikke snakke med seg selv, forstår du vel,» kom det prompte fra kameraten. Han hadde skjønt det.

\section{Kari Tveito}

kari.tveito@oslo-universitetssykehus.no Oslo universitetssykehus, Aker 